When I opened the envelope containing the December issue of the Forestry Chronicle, out dropped a dismal-brown-coloured booklet. It appeared to be the delayed arrival of a report published half a century ago. But no, the date was certainly 1964, so maybe it was an Australian or New Zealand publication sent along as a Christmas bonus. Closer inspection, however, revealed it was the 56th Annual Report of the Canadian Institute of Forestry. What virile colour! What a dynamic cover design: a prehistoric arrowhead and a cracked, impaled ping-pong ball sinking slowly into a mire!

Good grief, Mr. Editor, don't be so carried away with the power of the contents that you neglect the cover.

D. C. F. FAYLe

Does Animal Damage Deserve Further Research?

It is hoped that Mr. Mitchell's conclusions in his article "Height Growth Losses due to Animal Feeding on Vancouver Island", Forestry Chronicle, September, 1964 are not.construed as meaning that the subject of animal damage warrants no further research. If his conclusions are correct, which some field foresters find difficult to accept, and the economic losses are unimportant under extensive forest management, it should be remembered that intensive management is fast becoming a reality. Any loss of growth which will extend rotation is increasingly significant as foresters strive to shorten this period.

The individual studies, coordinated by the Reforestation Sub-committee of the Tree Farm Forestry Committee, of Revel, Bandy and Mitchell were attempts to interpret history. The results may have been masked by factors no longer evident when the appraisals were made. For example, it is known that deer select the highest protein food available when feeding; in the case of trees this is the most vigorous and the unbrowsed controls could have been poorer trees, and, therefore, slower growing and so not constitute a valid control. On page 303 Mitchell stated that, twelve years after planting, a severely browsed tree was 40" tall, and theorized that an unbrowsed tree would be about 60 " tall. Reference to U.S.D.A. Bulletin 201, "The Yield of Douglas Fir in the Pacific Northwest" shows that a natural seedling on site index 80-90 would reach $60^{\prime \prime}$ in eleven years. A planted tree should reach this height more quickly. Severe browsing is unusual on sites as low as this because they are unattractive to deer, being a poor food source. These examples represent annual growth rates of $2.5^{\prime \prime}$ and $4^{\prime \prime}$ assuming the tree was $10^{\prime \prime}$ tall when planted. This growth rate is unacceptable in a managed forest and, if animal feeding is not a major factor, research should be instituted to find out what is.

Our neighbors to the south are highly concerned, and all levels of government and industry are engaged in research leading to reduced animal damage. Losses of $\$ 15$ million annually were estimated several years ago in an article entitled "There's Trouble in the Woods", prepared by Northwest Forest Pest Action Council and distributed by Western Forestry and Conservation Association. Fortunately, Vancouver Island is not endowed with all the animals described by Lawrence, Kverno, and Hartwell in "Wildlife Feeding Injuries in the Pacific Northwest" (W.F.C.A.); however, deer, elk, and possibly sooty grouse are present in increasing numbers. 
A new project is needed to establish the facts about browsing. This would involve preparation of a working plan to include all possible factorse.g. range of soils, site indices, vegetational types, aspect, topography, etc. Trees should be planted in enclosures or protected by cages. Observations on each area should be made at least bi-annually-after winter, and after spring feeding, and both foresters and wildlife biologists should be employed on the project in a team effort.

It is trusted that this suggestion will receive serious consideration and that a project will in fact be established.

D. L. Handley and G. L. Ainscough

\section{CAN Genetics Solve Everything?}

A major part of the 1964 Northeastern Forest Tree Improvement Conference was devoted to an international conference on "Genetic Improvement for Disease and Insect Resistance of Forest Trees" jointly sponsored by NATO and the National Science Foundation and attended by delegates from some twelve nations. It was a privilege to attend a meeting so indicative of the importance of forestry in modern society and no interested observer could resist being impressed by the advances reported in resistance breeding and the bold plans for the future that were unveiled. One could easily begin to feel that the main highway to salvation is via selection and breeding. I hasten to add here that the tree breeders do not suggest that there are no other possibilities of avoiding or reducing insect and disease losses-no doubt they assume that other approaches are being explored by other people. It occurs to this member of the "other people" category that the search for other approaches may be less diligent than it should be. The following questions come to mind:

1. Are research findings in general being translated into improved silviculture, resulting in healthier, more resistant forests, as rapidly as they might be?

2. Is there any agency charged with the task of pointing out possible silvicultural applications of research results from specialized fields, or is this largely left to chance?

3. Is there too great a tendency to expect that the glamorous new science of genetics will solve all the problems?

4. Will resistance breeding with trees do more than cereal breeding has, i.e., hold the line against insects and disease?

5. Do research directors have the time and specialized advice they need to establish priorities for the different possible approaches to a given insect or disease problem?

Finally, to illustrate problems that might be partially, or even fully, solved by modifications in silviculture the following are suggested. Others might come to mind.

1. Perhaps all the white pine we need could be grown without much trouble from blister rust if the planting site zoning and climatic escape ideas worked out in the Lake States were to guide planting.

2. Perhaps the incidence of conditions favouring outbreak of the spruce budworm epidemics could be reduced to an acceptable level by modification in balsam fir silviculture and management. 